\title{
Effect of calcium-alginate bead and Anoectochilus formosanus Hayata extract fluid on the viability of Lactobacillus plantarum ATCC 8014 and bioactive compounds in fermented apple juice
}

\author{
${ }^{1 *}$ Lieu, M.D., ${ }^{1}$ Le, T.K.N., ${ }^{1}$ Nguyen T.L., ${ }^{2}$ Dang, T.K.T. and ${ }^{2}$ Do, D.G. \\ ${ }^{I}$ Faculty of Food Science and Technology, Ho Chi Minh City University of Food Industry, 140 Le Trong \\ Tan, Tay Thanh Ward, Tan Phu District, Ho Chi Minh City, Viet Nam \\ ${ }^{2}$ Department of Plant Cell Technology, Institute of Tropical Biology, 9/621 Ha Noi highway, Ho Chi Minh \\ City, Viet Nam
}

\begin{abstract}
Article history:
Received: 13 November 2019

Received in revised form: 21

December 2019

Accepted: 27 December 2019

Available Online: 4 January

2020
\end{abstract}

\section{Keywords:}

Alginate,

Anoectochilus formosanus,

Encapsulation,

Bioactivity,

Probiotic

\section{DOI:}

https://doi.org/10.26656/fr.2017.4(3).385

\begin{abstract}
The aim of this study was to determinate the effect of the encapsulation by calciumalginate containing (MA sample) or non-containing Anoectochilus formosanus Hayata extracted fluid (M sample) on the survival of Lactobacillus plantarum ATCC 8014 in fermented apple juice for 60 hours. The antioxidant activity, total polyphenol, polysaccharide, $\mathrm{pH}$ values, and the density of $L$. plantarum were determined every 12 hours of fermentation. The fermented apple juice was stored at $4^{\circ} \mathrm{C}$ in 5 weeks. The $\mathrm{pH}$ value and the viable $L$. plantarum were evaluated during storage and in the simulation gastric medium after 4 weeks of storage. The results showed that bioactive compounds increased in the first 24 hours but decreased slowly in subsequent hours of fermentation in which the sample containing encapsulated bead had better results than free cells (F samples). The scavenging activity DPPH, total polyphenol, and polysaccharide of the MA sample were $6.58 \mathrm{mg}$ Vit C/100mL; $304.65 \mathrm{mg} \mathrm{GAE} / 100 \mathrm{~mL}$; and $2.98 \mathrm{mg} \mathrm{Glu} / 100 \mathrm{~mL}$, respectively. The viability of $L$. plantarum was maintained over $6 \log \mathrm{CFU} / \mathrm{mL}$ for the encapsulated samples compared to $4 \log \mathrm{CFU} / \mathrm{mL}$ for the $\mathrm{F}$ samples. The viability of encapsulated L. plantarum in A and MA samples was no significant difference during storage, but the survival rate of L. plantarum in MA sample was significantly higher than M samples in the SGF (Simulated gastric fluid) medium. The results indicated that adding the $A$. formosanus Hayata extract fluid into the calcium-alginate matrix protected $L$. plantarum cells during fermentation, storage and in the SGF medium.
\end{abstract}

\section{Introduction}

Apple was the fruit (Malus domestica) used commonly in the whole world and contributed the benefits for human health. Bioactive substances in apple such as phytochemical, triterpenoid and fiber played an important role in defending cells against cancer, cardiovascular therapy, diabetes, asthma, pulmonary edema, aging-resistant and lose weight (Gerhauser 2008; Hyson 2011). Due to these advantages, apples have produced a variety of kind products including candy, apple jam, apple vinegar, and fermented apple juice. In the fermentation process, the activity of available enzymes in materials and bacterial metabolism transformed the nutrition and bioactivity compounds into the valued form for health. Simultaneously, the end products of fermentation such as ethanol, organic acid, and bacteriocin prevented again harmful bacteria in foods (Marco et al., 2017). Besides, using probiotic bacteria in fermentation not only produced many of advantaged metabolites but also contributed abundant sources of probiotic for customer health. However, the low $\mathrm{pH}$ value after fermentation processing, as well as storage time, would affect the viable probiotic. For commercial probiotic products, request for the viability of bacteria is a considered issue. Therefore, the choice of the method to protect probiotic cells is necessary, in which encapsulated technology considered very interesting. Encapsulated preparations contributed an anaerobic environment for sensitive probiotics, simultaneously, were the barrier prevented the impact of acidic environment (Ding and Shah. 2008). Materials often used in encapsulated technology were non-toxic and no effect to bacteria; thus, alginate used commonly in previous studies and protected effectively probiotic (Kailasapathy, 2002; Ding and Shah, 2008; Nualkaekul et al., 2012). Besides many benefits products like apples, 
surveys about herbal medicine realized that Anoectochilus formosanus Hayata with many herbal drug activities had the hepatoprotective effect, improved human immunity, and applied in cancer therapy (Tseng et al., 2006). Moreover, compounds in Anoectochilus formosanus Hayata have demonstrated a role as prebiotic (Yang et al., 2013). However, studies on the role of Anoectochilus formosanus Hayata on the survival of encapsulated probiotic in fermented apple juice, and the storage process was poorly reported. In this study, $A$. formosanus Hayata extracts adding in encapsulated calcium-alginate beads of Lactobacillus plantarum ATCC 8014 by extrusion method and adding to apple juice for 60 hours fermentation. Total polyphenol, the scavenging activity DPPH, polysaccharide, and $\mathrm{pH}$ changing were evaluated. The viability of probiotic was also determined during storage and simulated digestion environment.

\section{Materials and methods}

2.1 Preparations for apple juice and Anoectochilus formosanus Hayata extracts

Fuji apples were washed with water, cut into small pieces, and seed left. Then, apples were pressed into juice by juicer (Philips-HR1811) and stored at $4^{\circ} \mathrm{C}$

Anoectochilus formosanus Hayata (from Institute Tropical of Biology Ho Chi Minh City) were washed by saline then milled. Adding $100 \mathrm{~mL}$ of distilled water to $20 \mathrm{~g}$ of milled plant, this mix was homologized to receive the extracted liquid. The liquid was stored at $4^{\circ} \mathrm{C}$ until analysis.

\subsection{Preparations for microorganism}

Lactobacillus plantarum ATCC 8014 strains were incubated in $10 \mathrm{~mL}$ of MRS broth at $37^{\circ} \mathrm{C}$ in $24 \mathrm{hrs}$, then subculture in $90 \mathrm{~mL}$ of MRS broth in the same conditions. Biomass was received by centrifuge and suspended in $10 \mathrm{~mL}$ saline for the next encapsulated process.

\subsection{Encapsulation}

\subsubsection{Plasmolysis treatment}

The extrusion method using sodium-alginate was carried out according to methods of (Nualkaekul et al., 2012) with some modifies. The biomass of $L$. plantarum (in section 2.2) added into $20 \mathrm{~mL}$ of sodium-alginate $2 \%$ (w/v) (with or without $A$. formosanus extracted fluid 1\% $\mathrm{v} / \mathrm{v})$ ), and homogenized. Then, the mixture was extruded in $0.1 \mathrm{M} \mathrm{CaCl}_{2}$ solution by a piston and kept in 15 mins. The beads were filtered and washed with distilled water.

\subsection{Fermentation process}

L. plantarum in different forms including free cells (F), encapsulated bead (M), and encapsulated bead contained A. formosanus extracted fluid (MA) added into apple juice $(100 \mathrm{~mL})$ and fermented at $37^{\circ} \mathrm{C}$. The total polyphenol, the scavenging activity DPPH, polysaccharide, $\mathrm{pH}$ value, and the viable $L$. plantarum were determined in fermentation processing every 12 hrs. The $\mathrm{pH}$ value and the viable $L$. plantarum were evaluated every week of the storage of fermented apple juice for five weeks at $4^{\circ} \mathrm{C}$.

\subsection{Analytic method}

\subsubsection{Determination of scavenging activity DPPH}

DPPH test was carried out by the description of Mousavi et al. (2013) with some modifications. $1 \mathrm{~mL}$ sample diluted with $1 \mathrm{~mL}$ twice distilled water was adding into $10 \mathrm{~mL}$ of $0.1 \mathrm{mM}$ DPPH methanolic solution. This mixture was stored in dark conditions for 30 mins. Absorbance was measured triplicate by UV-Vis spectrophotometer at $517 \mathrm{~nm}$. Distilled water used as blank. The result was expressed by mg vitamin $\mathrm{C} / 100$ $\mathrm{mL}$ samples based on the calibration curve of authentic $\mathrm{L}$ -ascorbic acid.

\subsubsection{Determination of total phenolic}

Total phenolic was measured according to methods of Othman et al. (2009) with some changes. Firstly, 0.1 $\mathrm{mL}$ fermented juice and $0.9 \mathrm{~mL}$ twice distilled water were mixed, then add $5 \mathrm{~mL}$ of $10 \%$ Folin-Ciacalteu (v/ v). This mixture kept in 5 mins and added $4 \mathrm{~mL}$ of $7.5 \%$ $\mathrm{Na}_{2} \mathrm{CO}_{3}$ solution. The absorbance at $765 \mathrm{~nm}$ was read using a spectrophotometer. Blank treatment was prepared by distilled water. The total phenol value was calculated by $\mathrm{mg}$ GAE/100 $\mathrm{mL}$ based on the calibration curve of authentic gallic acid.

\subsubsection{Determination of polysaccharide}

Polysaccharide test was referred to Le et al. (2019) with some modifications. The polysaccharide was recovered after $24 \mathrm{hrs}$ at $4^{\circ} \mathrm{C}$ from mixture sample: Ethanol $(1: 5, \mathrm{v} / \mathrm{v})$ by centrifuge $5000 \mathrm{rpm}$ in $10 \mathrm{mins}$. The polysaccharide was diluted by $10 \mathrm{~mL}$ of distilled water (solution B). Then $0.1 \mathrm{~mL}$ solution $\mathrm{B}$ and $1.9 \mathrm{~mL}$ twice distilled water added into $8 \mathrm{~mL}$ of Anthrone reagents $2 \%(\mathrm{w} / \mathrm{v})$. Measurement of absorbance at 630 $\mathrm{nm}$ was carried out triplicate. Distilled water was used as blank. The result was displayed by $\mathrm{mg}$ Glucose $/ 100 \mathrm{~mL}$ on the basic of the calibration curve of glucose.

\subsubsection{Simulated gastric and intestinal fluid (SGF and SIF) experiments}

SGF and SIF environments were prepared according 
to the method of Lieu et al. (2017). SGF contained $9 \mathrm{~g} / \mathrm{L}$ $\mathrm{NaCl}, 3 \mathrm{~g} / \mathrm{L}$ pepsin, and adjusted $\mathrm{pH}$ to 2.0 by $5 \mathrm{~N} \mathrm{HCl}$ solution. SIF included $9 \mathrm{~g} / \mathrm{L} \mathrm{NaCl}, 3 \mathrm{~g} / \mathrm{L}$ beef bile, and adjusted $\mathrm{pH}$ to 6.5 by $5 \mathrm{M} \mathrm{NaOH}$ solution. The juice was incubated in SGF for $2 \mathrm{hrs}$ and in SIF for $4 \mathrm{hrs}$. The viable $L$. plantarum was determined indirectly by the plate count method.

\subsubsection{Determination of the survival of Lactobacillus} plantarum during fermentation, storage, and simulated gastric intestinal

A total of $10 \mathrm{~mL}$ of sample and $90 \mathrm{~mL}$ of $\mathrm{pH}$ buffer 7.0 were mixed and carried out by the stomacher in 15 mins. The sample was diluted and determine the viability of $L$. plantarum by the plate count method in MRS agar at $37^{\circ} \mathrm{C}$ for $24 \mathrm{hrs}$.

\subsection{Statistical analysis}

The data analysis was carried out using Statgraphics 15.1 software. The result was recorded as mean \pm standard deviation. Significant differences between means were determined by LSD test of ANOVA procedures $(p<0.05)$. Graphs were described by Microsoft Office Excel 2010.

\section{Results and discussion}

3.1 Effect of fermentation on the DPPH radical scavenging activity, total polyphenol and polysaccharide contents

The DPPH radical scavenging activity (mg $\mathrm{VitC} / 100 \mathrm{~mL}$ ) of all fermented juices is shown in Figure 1. The scavenging activity trended to enhance maximum at $24 \mathrm{hrs}$ and decrease gradually in the next fermented time for MA $(6.58 \pm 0.28 \mathrm{mg}$ vitC/100 mL) and $\mathrm{M}$ $(6.67 \pm 0.38 \mathrm{mg} v i t C / 100 \mathrm{~mL})$. In contrast, apple juice with free cells showed a trend to decline DPPH radicalscavenging activity by $50 \%$ compared to the initial $(p<0.05)$ (Figure 1). The results showed that all the samples decreased the scavenging activity after the fermentation process (Figure 1). The previous study showed that DPPH radical-scavenging activity enhanced after fermentation (Sabokbar et al., 2016; Le et al., 2019). Le et al. (2019) indicated that lactic fermentation increases the extracted efficiency of the bioactive compounds in $A$. formosanus compared to microwave and ultrasonic treatments. Similarly, the antioxidant activity of fermented pomegranate juice improved regard to the increase of free phenolic content, and products of other metabolic occurred during fermentation (Mousavi et al., 2013). Pyo et al. (2005) indicated that the antioxidant activity enhanced due to the release of aglycone through biologic metabolism during fermentation (Pyo et al., 2005). Li et al. (2012) indicated that the surface of $L$. plantarum contained protein and polysaccharide that could improve the antioxidant activity. However, modifications could lose these compounds, which caused the decline of DPPH radicalscavenging activity (Li et al., 2012). That would be that metabolisms in the matrix of the material occurred at a particular moment, which improved antioxidant activity but decreased it in the subsequent time.

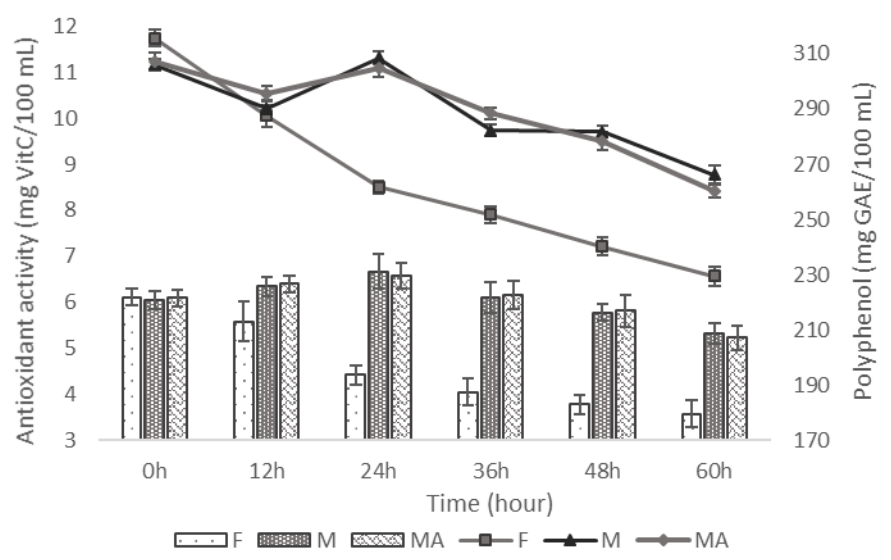

Figure 1. Antioxidant activity (column graph) and total polyphenol (line graph) during fermentation

The changing of total phenolics is indicated in Figure 1. Total phenol content trended decline absolutely in all fermented samples. The samples containing free cells (F samples) decreased completely for 60 hours fermentation $(315.65 \pm 3.11 \mathrm{mg} \mathrm{GAE} / \mathrm{mL}$ to $229.45 \pm 3.44$ $\mathrm{mg}$ GAE/100 mL). Total phenol content in $\mathrm{M}$ and MA samples decreased from $305.96 \pm 2.15$ and $307.24 \pm 3.05$ $\mathrm{mg} \mathrm{GAE} / 100 \mathrm{~mL}$ to $266.24 \pm 3.44$ and $260.22 \pm 2.45 \mathrm{mg}$ $\mathrm{GAE} / 100 \mathrm{~mL}$, respectively. In $\mathrm{M}$ and MA samples, at first $12 \mathrm{hrs}$, polyphenol content decreased dramatically but enhanced at 24 hours and continuously declined in the next period. In previous studies, the decrease of polyphenol was due to the appearance of biofilms preventing the release of phenolic compounds and affected by phenolics metabolic procedure by $L$. plantarum (Othman et al., 2009; Hashemi et al., 2017). After fermentation processing, the total phenolics level might enhance or decrease the initial value due to the metabolism of probiotic (Đorđević et al., 2010). The loss of polyphenol content during fermentation caused the reduction of antioxidant capacity (Othman et al., 2009). Materials matrix could influence on metabolic activity and biologic converts of cells.

The results of the polysaccharide content test are shown in Figure 2. Although samples adding encapsulated beads reduced polysaccharide content during fermentation, their glucose level was higher than that of free cells. Polysaccharide content at 60 hours was $2.78 \pm 0.10 ; 2.65 \pm 0.07$; and $1.56 \pm 0.11 \mathrm{~g} \mathrm{Glu} / 100 \mathrm{~mL}$ for MA; M; and F samples respectively, which reduced $13 \%$ 
and $52 \%$ than initial for encapsulated and nonencapsulated cells. The results showed that free probiotic cells consumed more sugars than encapsulated cells. The sugars level declined significantly during fermentation. In the fermentation procedure, the bacteria cells participated in converting glucose and fructose as carbon energy resources for metabolism in which $L$. plantarum strains consume more glucose than fructose (Mousavi et al., 2013). The carbohydrate converts by L. plantarum calculated on Glucose value occurred in the sample with free cells faster than that of encapsulated cells (Hashemi et al., 2017). The results from Figure 1 and Figure 2 showed that most of the biologic metabolism happened in the first 24 hours, and there was no significant change if extending fermentation time. Therefore, $24 \mathrm{hrs}$ of fermentation was an appropriate moment to finish the fermentation procedure.

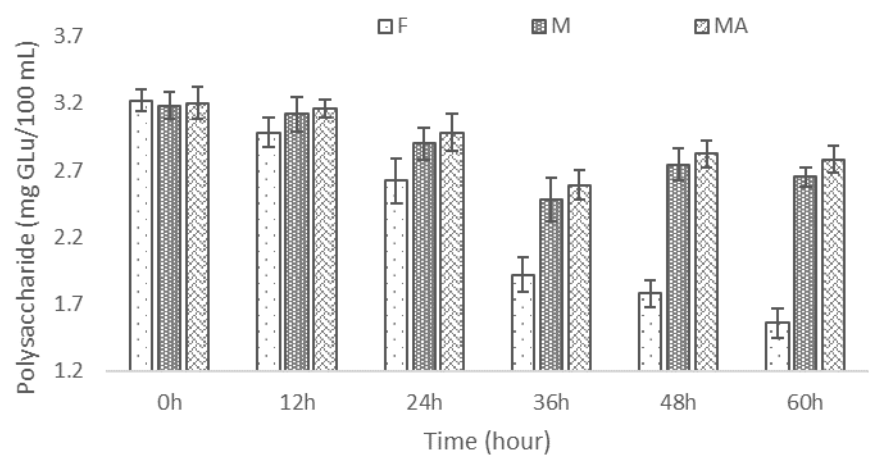

Figure 2. Polysaccharide data during fermentation

\subsection{Changes of $p H$ value and the viability of Lactobacillus plantarum during fermentation}

The $\mathrm{pH}$ value of $\mathrm{M}$ and $\mathrm{MA}$ samples after fermentation increased from the initial $\mathrm{pH}$ value of 3.71 to 3.84 and 3.81 respectively (Figure 3 ). In contrast, the $\mathrm{F}$ samples declined to 3.45 compared to the initial $\mathrm{pH}$ value. At $24 \mathrm{hrs}$ of fermentation, the $\mathrm{pH}$ values of three samples were $3.96-4.09$ (Figure 3), which in the safe $\mathrm{pH}$ value for storage (Costa et al., 2013). Roberts et al. (2018) reported that the $\mathrm{pH}$ value of fermented apple juice containing free or encapsulated cells has a significant difference after 72 hours of fermentation, in which the $\mathrm{pH}$ value of the free cell sample was lower than encapsulated samples. The results indicated that free probiotic cells produced more acid than encapsulated probiotic. Due to the protective capacity of the matrix, the $\mathrm{pH}$ value of fermented juice containing encapsulated bacteria changed insignificantly (Antunes et al., 2013).

At 60 hours of fermentation, the viability of $L$. plantarum in $\mathrm{F}, \mathrm{M}$, and MA samples were respectively $6.48 \pm 0.22 ; 7.37 \pm 0.28 ;$ and $7.97 \pm 0.27 \quad \log \quad \mathrm{CFU} / \mathrm{mL}$ (Figure 3). The results realized that there was a significant difference through 60 hours fermentation of apple juice $(p<0.05)$. All the samples had a trend to decrease the viable L. plantarum during fermentation, in which the viable $L$. plantarum in $\mathrm{F}$ samples was lower than encapsulated samples. In the first $24 \mathrm{hrs}$ of fermentation, the viable $L$. plantarum in F samples was reduced approximately $4 \log \mathrm{CFU} / \mathrm{mL}$ compared to 2.10 to $2.75 \log \mathrm{CFU} / \mathrm{mL}$ in the encapsulated samples. The viable $L$. plantarum in all samples was stable to the last of fermentation. In the previous study, the viability of probiotic bacteria in the fermented pomegranate juice was decreased in the first $24 \mathrm{hrs}$ of fermentation (Mousavi et al., 2013). The results due to the difference in the $\mathrm{pH}$ value of the fruit juice and the preliminary culture medium in which the low $\mathrm{pH}$ of fruit juice caused the vibration for probiotic bacteria leading to a decrease in the survival of probiotic bacteria. Moreover, the appearance of acetic acid, lactic acid, hydroperoxide, oxygen, and low $\mathrm{pH}$ decreased the survival ability of probiotic strain (Rokka and Rantamäki, 2010). Though alginate matrix could limit the impact of acid released from juice and maintains the sensory of foods, the alginate matrix did not protect probiotic bacteria against the adverse medium completely (Sohail et al., 2012). Therefore, adding the support component into the gel matrix is necessary to improve the viable probiotic bacteria. Yang et al. (2012) indicated that polysaccharides extracted from $A$. formosanus affected positively on the growth of Bifidobacterium breve 2.5 times higher than using inulin in the in vitro test. In the present study, the viable L. plantarum in MA samples was slightly higher than that of $\mathrm{M}$ samples, but a significant difference was not recorded.

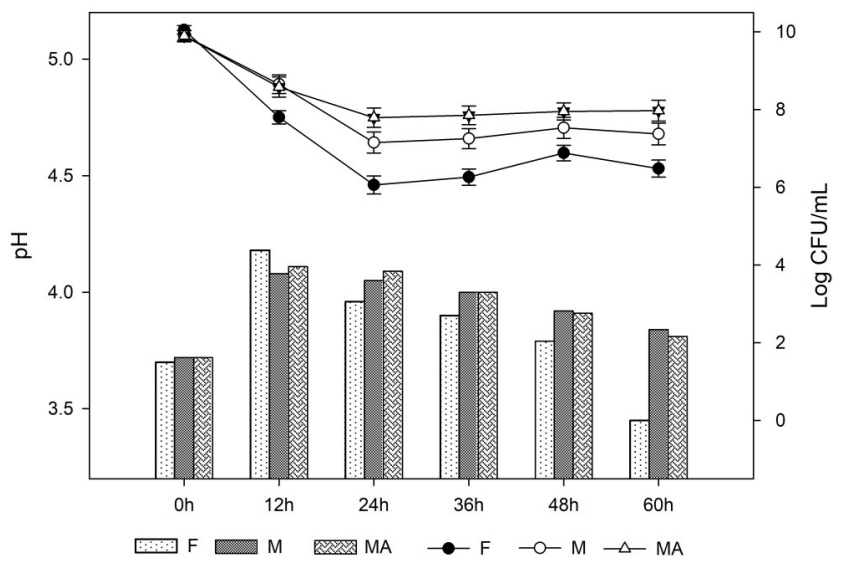

Figure 3. $\mathrm{pH}$ value (column graph) and the viability of $L$. plantarum (line graph) during fermentation.

\subsection{Effect of microencapsulation on $\mathrm{pH}$ value and viability of Lactobacillus plantarum during storage}

During storage time, the change of $\mathrm{pH}$ occurred in all the samples (Figure 4). The $\mathrm{pH}$ values of MA and $\mathrm{M}$ samples (4.09 and 4.05 initially) were declined to 3.65 and 3.70 respectively. The juice fermented by free cells declined from 3.96 to 3.09. Both encapsulated treatment 
and free cells affected $\mathrm{pH}$ value in preservation. The previous studies carried out the experiments to control the change of $\mathrm{pH}$ during storage weeks (Ding et al., 2008; Sohail et al., 2012; Antunes et al., 2013). Ding et al. (2008) indicated that the $\mathrm{pH}$ value of fermented fruit juice containing free probiotic cells was reduced significantly compared to encapsulated cell samples during six weeks of storage. Similar, the $\mathrm{pH}$ of orange juice containing encapsulated probiotics (alginate $2 \% \mathrm{w} /$ v) was significantly $(p<0.05)$ higher than that containing free probiotic bacteria (Sohail et al., 2012). This phenomenon could be explained that free cells bacteria were unstable in the low $\mathrm{pH}$ environment, and the release of sugars disintegrated enzymes from dead bacteria declined $\mathrm{pH}$ value. It's demonstrated that microencapsulation contributed protective ability for bacteria cells during storage and had a higher $\mathrm{pH}$ value than free cells (Antunes et al., 2013).

The results of the viable $L$. plantarum showed that free probiotic cells had the lowest survival rate with 3 $\log \mathrm{CFU} / \mathrm{mL}$ of loss after five weeks of storage compared to the encapsulated cells with $3.34 \pm 0.25$; $5.28 \pm 0.16$; and $5.82 \pm 0.24 \log \mathrm{CFU} / \mathrm{mL}$ for $\mathrm{F}, \mathrm{M}$ and $\mathrm{MA}$ samples respectively (Figure 4). After four weeks of storage, the fermented apple juice containing encapsulated probiotics maintained above $6 \log \mathrm{CFU} / \mathrm{mL}$ that appropriate to the requirements of functional foods. The encapsulation technique contributed to an anaerobic environment suitable for sensitive bacteria, simultaneously, was the barrier again the acidic environment in juice, the low $\mathrm{pH}$ and digestive enzyme (Ding and Shah, 2008). Besides, encapsulated beads protect probiotic cells to avoid damages from the adverse medium such as cold storage, and the digestive system (Krasaekoopt et al., 2003). The results from the present study suggested that the viability of $L$. plantarum could stable maintain during four weeks of storage at $4^{\circ} \mathrm{C}$, which might meet completely demands to improve the survival rate of probiotic.

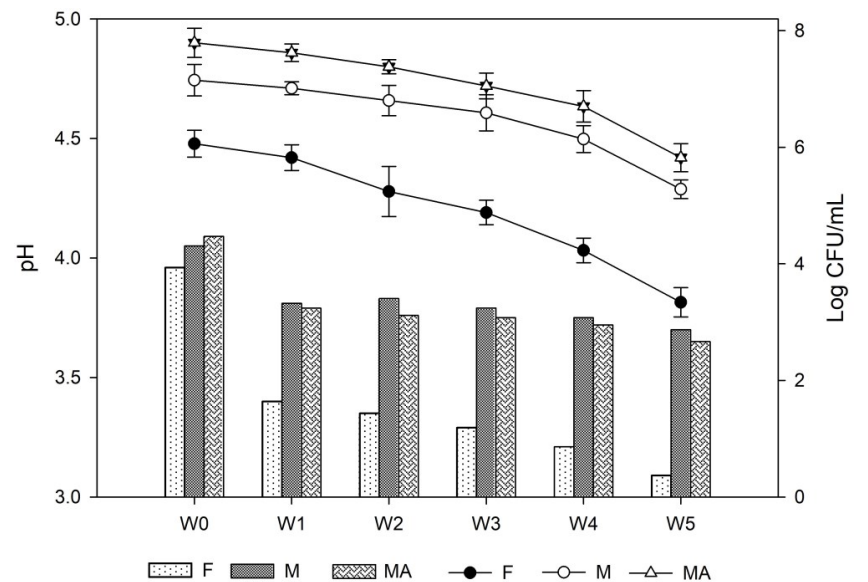

Figure 4. $\mathrm{pH}$ value (column graph) and the viability of $L$. plantarum (line graph) during storage.
3.4 Viability of Lactobacillus plantarum ATCC 8014 in SGF and SIF

The survival rate of $L$. plantarum in the simulated gastric intestinal after four weeks of storage was presented in Figure 5. In the SGF assay, the viability of L. plantarum in the $\mathrm{F}$ samples was lost completely, whereas one to two $\log \mathrm{CFU} / \mathrm{mL}$ loss was recorded in the $\mathrm{M}$ and MA samples (Figure 5). The previous study demonstrated that the resistance of bacteria decreased significantly in the low pH of SGF (Lieu et al., 2017; Roberts et al., 2018). Therefore, microencapsulation protected bacteria cells from the impacts of low $\mathrm{pH}$ in the gastric environment (Nualkaekul et al., 2012). In the SIF assay, the survival rate of $L$. plantarum in F, M, and MA samples were $3.11 \pm 0.32 ; 5.66 \pm 0.22,5.05 \pm 0.17 \log$ $\mathrm{CFU} / \mathrm{mL}$ respectively. A similar result was reported by Nualkaekul et al. (2012) showed that probiotic bacteria was not sensitive in the SIF as much as that in the SGF medium.

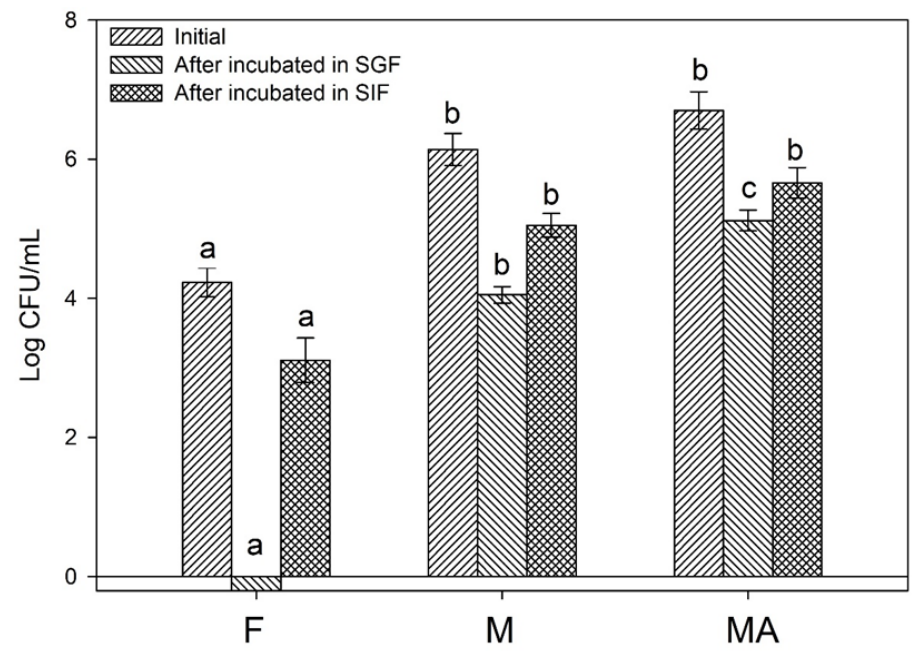

Figure 5. The viability of $L$. plantarum after SGF and SIF. Different letters above the bars indicate significant difference among samples $(p<0.05)$.

The previous studies showed that prebiotic improved significantly the viability of probiotic bacteria in the simulated gastric fluid (Kingwatee et al., 2014; Lieu et al., 2017). Kingwatee et al. (2014) indicated that inulin $5 \%(\mathrm{w} / \mathrm{v})$ improved significantly the resistance of Lactobacillus casei 01 against the gastrointestinal environment. Besides, the study of Yang et al. (2012) demonstrated that $A$. formosanus extract fluid could improve the growth of probiotic bacteria that 2.5 times higher compared to inulin. In the present study, it is interesting to note that the viability of encapsulated $L$. plantarum in $\mathrm{M}$ and MA samples were no significant difference $(p>0.05)$ during storage (Figure 4), but the survival rate of $L$. plantarum in MA sample was significantly higher $(p<0.05)$ than $\mathrm{M}$ samples after 2 hours incubation in SGF medium (Figure 5). $A$. formosanus extracts improved the viability of probiotic 
bacteria due to the adjustment of ATP transportation - a part of nutritional absorbance ( $\mathrm{Lu}$ et al. 2013). This mechanism would help the survival rate of L. plantarum in MA samples was improved higher than $M$ samples (Figure 5).

\section{Conclusion}

Probiotic cells encapsulating by calcium-alginate $2 \%$ (w/v) containing A. formosanus extracted fluid showed the best protection and preservation capacity. The DPPH scavenging activity, total polyphenol, and polysaccharide decreased trendy during fermentation in all samples, especially juice adding the free cells, and $24 \mathrm{hrs}$ of fermentation process was a suitable moment to finish the fermentation. The resistance of encapsulated probiotics in fermentation and storage was improved effectively. The results of SGF and SIF assay showed that plant extracted fluid from $A$. formosanus in MA samples improved the resistance of $L$. plantarum under the low $\mathrm{pH}$ impact and hydrolytic enzymes.

\section{References}

Antunes, A., Liserre, A., Coelho, A., Menezes, C., Moreno, I., Yotsuyanagi, K. and Azambuja, N. (2013). Acerola nectar with added microencapsulated probiotic. LWT-Food Science and Technology, 54(1), 125-131. https://doi.org/10.1016/ j.lwt.2013.04.018

Costa, M.G.M., Fonteles, T.V., de Jesus, A.L.T. and Rodrigues, S. (2013). Sonicated pineapple juice as substrate for $L$. casei cultivation for probiotic beverage development: process optimisation and product stability. Food Chemistry, 139(1-4), 261266.

Ding, W. and Shah, N.P. (2008). Survival of free and microencapsulated probiotic bacteria in orange and apple juices. International Food Research Journal, 15(2), 219-232.

Đorđević, T.M., Šiler-Marinković, S.S. and Dimitrijević -Branković, S.I. (2010). Effect of fermentation on antioxidant properties of some cereals and pseudo cereals. Food Chemistry, 119(3), 957-963. https:// doi.org/10.1016/j.foodchem.2009.07.049

Gerhauser, C. (2008). Cancer chemopreventive potential of apples, apple juice, and apple components. Planta Medica, 74(13), 1608-1624. https://doi.org/10.1055/s $-0028-1088300$

Hashemi, S.M.B., Khaneghah, A.M., Barba, F.J., Nemati, Z., Shokofti, S.S. and Alizadeh, F. (2017). Fermented sweet lemon juice (Citrus limetta) using Lactobacillus plantarum LS5: Chemical composition, antioxidant and antibacterial activities.
Journal of Functional Foods, 38(Part A), 409-414. https://doi.org/10.1016/j.jff.2017.09.040

Hyson, D.A. (2011). A comprehensive review of apples and apple components and their relationship to human health. Advances in Nutrition, 2(5), 408-420. https://doi.org/10.3945/an.111.000513

Kailasapathy, K. (2002). Microencapsulation of probiotic bacteria: technology and potential applications. Current Issues in Intestinal Microbiology, 3(2), 3948.

Kingwatee, N., Apichartsrangkoon, A., Chaikham, P., Pankasemsuk, T. and Changrue, V. (2014). Survivability and metabolic activity of Lactobacillus casei 01 incorporating lychee juice plus inulin under simulated gastrointestinal environment. International Food Research Journal, 21(1), 83-89.

Krasaekoopt, W., Bhandari, B. and Deeth, H. (2003). Evaluation of encapsulation techniques of probiotics for yoghurt. International Dairy Journal, 13(1), 313. https://doi.org/10.1016/S0958-6946(02)00155-3

Le, T.K.N., Nguyen, T.L., Nguyen, T.T., Dang, T.K.T., Do, D.G. and Lieu, M.D. (2019). Extraction of Bioactive Component from Herbal Anoectochilus formosanus Hayata by Microwave, Ultrasound and Lactic Fermentation. Turkish Journal of AgricultureFood Science and Technology, 7(4), 593-597.

Li, S., Zhao, Y., Zhang, L., Zhang, X., Huang, L., Li, D., Niu, C., Yang, Z. and Wang, Q. (2012). Antioxidant activity of Lactobacillus plantarum strains isolated from traditional Chinese fermented foods. Food Chemistry, 135(3), 1914-1919. https:// doi.org/10.1016/j.foodchem.2012.06.048

Lieu, M.D., Dang, T.K.T. and Nguyen, T.H. (2017). Viability of microencapsulated Lactobacillus casei in synbiotic mayonnaise. Food Research, 1(6), 234239. https://doi.org/10.26656/fr.2017.6.103

Marco, M.L., Heeney, D. Binda, S.J. Cifelli, C.J., Cotter, P.D., Foligné, B., Gänzle, M., Kort, R., Pasin, G. and Pihlanto, A. (2017). Health benefits of fermented foods: microbiota and beyond. Current Opinion in Biotechnology, 44, 94-102. https://doi.org/10.1016/ j.copbio.2016.11.010

Mousavi, Z.E.S. Mousavi, S.M., Razavi, S.H., Hadinejad, M., Emam-Djomeh, Z. and Mirzapour, M. (2013). Effect of fermentation of pomegranate juice by Lactobacillus plantarum and Lactobacillus acidophilus on the antioxidant activity and metabolism of sugars, organic acids and phenolic compounds. Food Biotechnology, 27(1), 1-13. https://doi.org/10.1080/08905436.2012.724037

Nualkaekul, S., Lenton, D., Cook, M.T., Khutoryanskiy, V.V. and Charalampopoulos, D. (2012). Chitosan 
coated alginate beads for the survival of microencapsulated Lactobacillus plantarum in pomegranate juice. Carbohydrate Polymers, 90(3), 1281-1287. https://doi.org/10.1016/ j.carbpol.2012.06.073

Othman, N.B., Roblain, D., Chammen, N., Thonart, P. and Hamdi, M. (2009). Antioxidant phenolic compounds loss during the fermentation of Chétoui olives. Food Chemistry, 116(3), 662-669. https:// doi.org/10.1016/j.foodchem.2009.02.084

Pyo, Y.H., Lee, T.C. and Lee, Y.C. (2005). Effect of lactic acid fermentation on enrichment of antioxidant properties and bioactive isoflavones in soybean. Journal of Food Science, 70(3), S215-S220. https:// doi.org/10.1111/j.1365-2621.2005.tb07160.x

Roberts, D., Reyes, V., Bonilla, F., Dzandu, B., Liu, C., Chouljenko, A. and Sathivel, S. (2018). Viability of Lactobacillus plantarum NCIMB 8826 in fermented apple juice under simulated gastric and intestinal conditions. LWT, 97, 144-150. https:// doi.org/10.1016/j.lwt.2018.06.036

Rokka, S. and Rantamäki, P. (2010). Protecting probiotic bacteria by microencapsulation: challenges for industrial applications. European Food Research and Technology, 231(1), 1-12. https:// doi.org/10.1007/s00217-010-1246-2

Sabokbar, N. and Khodaiyan, F. (2016). Total phenolic content and antioxidant activities of pomegranate juice and whey based novel beverage fermented by kefir grains. Journal of Food Science and Technology, 53(1), 739-747. https://doi.org/10.1007/ s13197-015-2029-3

Sohail, A., Turner, M.S., Prabawati, E.K., Coombes, A.G. and Bhandari, B. (2012). Evaluation of Lactobacillus rhamnosus GG and Lactobacillus acidophilus NCFM encapsulated using a novel impinging aerosol method in fruit food products. International Journal of Food Microbiology, 157(2), 162-166. https://doi.org/10.1016/ j.ijfoodmicro.2012.04.025

Tseng, C.-C., Shang, H.-F., Wang, L.-F., Su, B., Hsu, C.C., Kao, H.-Y. and Cheng, K.-T. (2006). Antitumor and immunostimulating effects of Anoectochilus formosanus Hayata. Phytomedicine, 13(5), 366-370. https://doi.org/10.1016/j.phymed.2004.01.016

Yang, L.-C., Lin, W.-C. and Lu, T.-J. (2012). Characterization and prebiotic activity of aqueous extract and indigestible polysaccharide from Anoectochilus formosanus. Journal of Agricultural and Food Chemistry, 60(35), 8590-8599. https:// doi.org/10.1021/jf3018832
Yang, L.-C., Lu, T.-J. and Lin, W.-C. (2013). The prebiotic arabinogalactan of Anoectochilus formosanus prevents ovariectomy-induced osteoporosis in mice. Journal of Functional Foods, 5 (4), 1642-1653. https://doi.org/10.1016/ j.jff.2013.07.006 